\title{
CTNNA2 wt Allele
}

National Cancer Institute

\section{Source}

National Cancer Institute. CTNNA2 wt Allele. NCI Thesaurus. Code C143116.

Human CTNNA2 wild-type allele is located in the vicinity of 2p12 and is approximately $1464 \mathrm{~kb}$ in length. This allele, which encodes catenin alpha-2 protein, plays a role in neuronal differentiation. 